\title{
RGD Motif
}

National Cancer Institute

\section{Source}

National Cancer Institute. RGD Motif. NCI Thesaurus. Code C13288.

A consensus tripeptide that is recognized by and for binding to proteins of the integrin family, including many cell adhesion molecules. The one-letter codes for arg inine - glycine - aspartic acid. This motif can be found in proteins of the extracellular matrix and it is recognized by different members of the integrin family. The structure of the tenth type III module of fibronectin has shown that the RGD motif lies on a flexible loop. 